\title{
OPINION ABOUT EXERCISES IN WATER AND LIFESTYLE OF WOMEN ATTENDING AQUA AEROBICS CLASSES
}

\author{
Alicja Drohomirecka, ${ }^{1, A, C, D}$ Justyna Wojciuszkiewicz', A, B, C, D \\ 1 Faculty of Physical Culture and Health Promotion, University of Szczecin, Poland \\ 2 Student of the Faculty of Physical Culture and Health Promotion, University of Szczecin, Poland

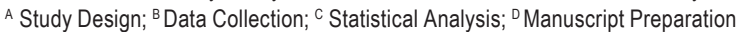 \\ Address for corpespondence: \\ Justyna Wojciuszkiewicz \\ University of Szczecin, Faculty of Physical Culture and Health Promotion \\ Al. Piastów 40b, building 6, 71-065 Szczecin, Poland \\ E-mail: j.wojciuszkiewicz@wp.pl
}

\begin{abstract}
Ahstract. Aqua aerobics, as one of the modern forms of movement, is becoming more and more popular among the public. The main objectives of this study is to get to know the lifestyle and opinion on the aqua aerobic classes of women participating in this type of activities. According to the authors, people who take part in aqua aerobics classes probably care about their fitness. They should also be aware of the need to lead a healthy lifestyle, because it is one of the most important factors in human health.

The study group included 50 participants of aqua aerobics classes in "AQUA STYL" company in Szczecin. Each subject received a questionnaire. It contained 23 questions. Most of the questions related to information about participants and their way of life. The other concerned the opinion about aqua aerobic classes.

Most of the respondents answered that they lead a healthy lifestyle. More than $70 \%$ of women felt that they follow rather healthy diet. The analysis showed that aqua aerobics gave pleasure to almost all respondents. The benefit of participation in aqua aerobics classes is generally better mood.

Despite the large number of people declaring a healthy lifestyle, it is advisable to increase the awareness of the lifelong need for physical activity. As many as $30 \%$ of respondents did not know if they lead a healthy lifestyle. There should be greater promotion of healthy behavior. Instructors should know more about the group attending the classes, in order to make the exercises more attractive and effective.
\end{abstract}

Key worll: aqua aerobics, life style

\section{Introduction}

Aqua aerobics, as one of the modern forms of movement is becoming more and more popular among the public (Pietrusik, Mroczek, 2003; Eider, Eider, 2006). Among others, Zysiak-Christ, Figurska, Stasikowska (2010) describes its positive influence on the human locomotion and the development of various motor skills. One of the elements that affect such a broad interest in aqua aerobics are specific characteristics of the aquatic environment (Mosakowska, 2007). From the standpoint of physics and physiology, aqueous media are preferred in the treatment 
of various diseases of the musculoskeletal or neurological system, also in the pathology of heart and lungs (Jung, Chung, Kim, Lee, Lee, 2014). Katz (2003) points out that many pregnant women attend various activities taking place in an aqueous environment, because it has a significant beneficial effect on the cardiovascular system due to hydrostatic pressure. The diverse nature of activities, based on the appropriate accessories and appliances usage that shapes the individual parts of the body is also a factor encouraging to participate in this form of exercises (Zysiak-Christ, Figurska, Stasikowska, 2010).

According to the authors, people who take part in aqua aerobics classes probably care about their fitness. They should also be aware of the need to lead a healthy lifestyle, because it is one of the most important factors in human health (Drabik, Resiak, 2010). Sęk (2000) defines lifestyle as characteristic behavior of a particular individual or social group, which is essential for health. Some lifestyle behaviors are considered as possible determinants and causes of not only coronary heart disease and other diseases of the cardiovascular system, but also cancer and high mortality (Menotti, Puddu, Maiani, Catasta, 2014, 2015; Prinelli et al., 2015). These behaviors can be: regular physical exercises, proper nutrition, lack of bad habits, adequate sleep and avoidance of stimulants (Mędrela-Kuder, 2004; Sęk, 2000; Sygit, Sygit, 2008). One of the most important factors in lifestyle is physical activity (Drabik, Resiak, 2010; Nowak, 2008).

The main objectives of this study is to get to know the lifestyle and opinion on the aqua aerobics classes of women participating in this type of activities. Instructors' knowledge about the needs, expectations and beliefs of participants is an important factor contributing to the increase of the classes' attractiveness. Thanks to such an attitude companies operating in recreation industry will be able to improve employees' qualifications. This study is designed to reveal the participants' opinion and assess the services provided by the company "AQUA STYL" in Szczecin.

Personal questionnaire included questions verifying the healthy lifestyle-of participants of aqua aerobics classes, according to the criteria given by the literature (Sęk, 2000; Mędrela-Kuder, 2004; Nowak, 2008; Sygit, Sygit, 2008; Drabik, Resiak, 2010). The study aimed at verifying the above theses and introducing potential changes in the life habits of individuals.

\section{Subjects and methods}

The study group included 50 participants of aqua aerobics classes in "AQUA STYL" company in Szczecin. The classes took part in two swimming pools in Szczecin, three times a week, at the Gymnasium no. 9 (Dunikowskiego Street 1), and twice at the SDS swimming pool (Waska Street 16). The company has been providing its services since November 2009.

Each subject received a questionnaire before the session, which she took home, filled in and brought to the next class. It contained 23 questions. Most of the questions related to information about participants and their lifestyle. The other associated with the opinion about aqua aerobics classes.

The questionnaire consisted of questions closed and open questions which enabled the subjects to enter their own response. The results were compiled and presented on the charts in percentages.

\section{Results}

The majority of respondents - $68 \%$ - answered affirmatively to the question: "Do you lead a healthy lifestyle?". For comparison, only $2 \%$ answered negatively (Figure 1 ). 


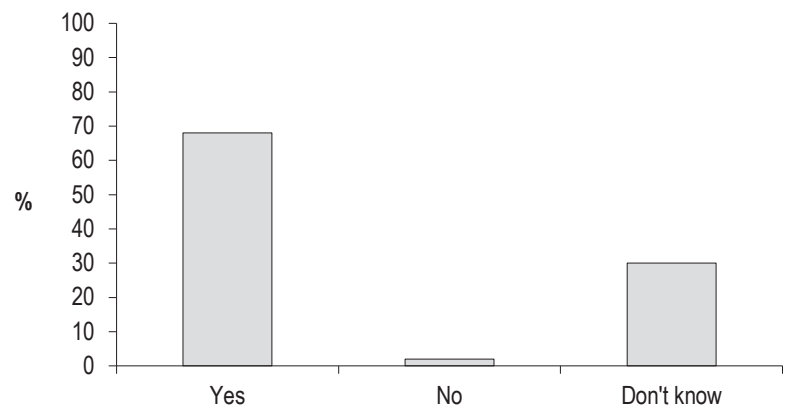

Figure 1. Respondents living a healthy lifestyle

Women participating in the study were asked for a subjective assessment of the current state of health. Almost $60 \%$ of respondents rated their health as good, while $10 \%$ found it to be very good (Figure 2).

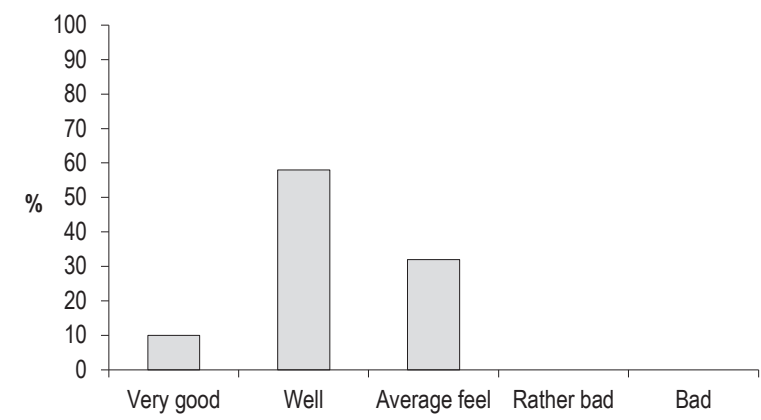

Figure 2. Respondents' current health in self-opinion

Studies have shown that a majority of respondents $-82 \%$ did not smoke cigarettes (Figure 3).

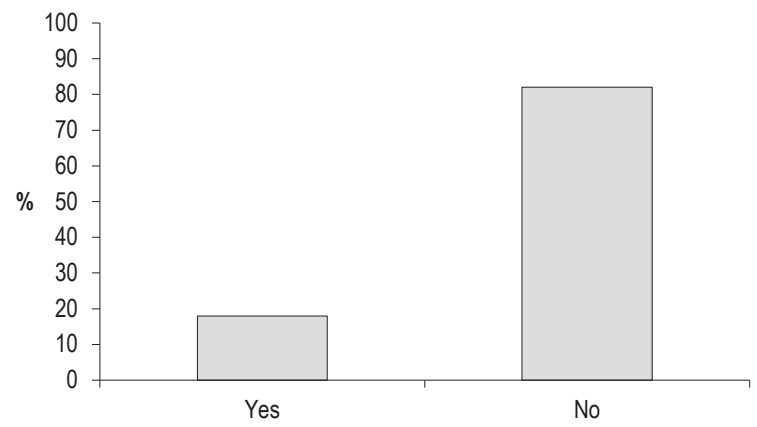

Figure 3. Smoking cigarettes 
Next question required the respondents to express an evaluation of their diet. In the study group, $72 \%$ of women felt that they eat rather healthily. On the other hand, only $2 \%$ of respondents marked that they do not follow healthy diet and also 2\% "don't know" if they follow it (Figure 4).

The majority of respondents $-66 \%$ - were active-in their free time. Other subjects - $34 \%$ - spent it passively (Figure 5).

The analysis of the study shows that aqua aerobics gave pleasure to almost all the respondents (Figure 6).

Most of the study group - $82 \%$ - answered that they like the music proposed during aqua aerobics classes. The remaining percentage - $18 \%$ - suggests changing tracks (Figure 7 ).

The next question concerned the benefits, that the respondents noticed through participation in aqua aerobics. Most of subjects selected the answers "better mood" and "fitness improvement". Answers: "weight loss" and "eliminating ailments" were marked by $20 \%$ of women (Figure 8 ).

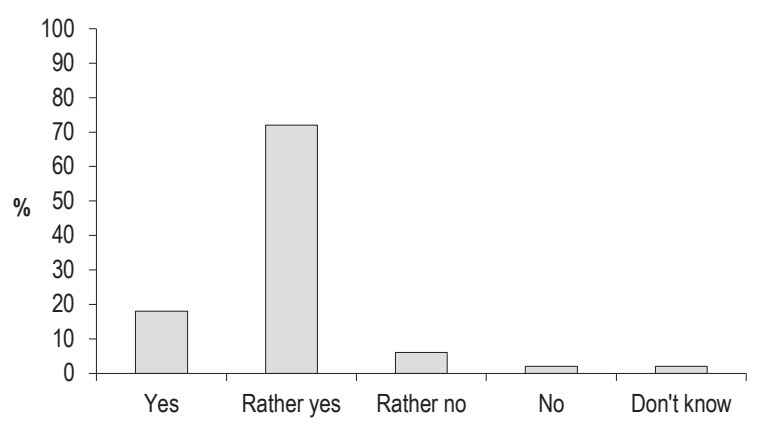

Figure 4. Respondents following healthy diet

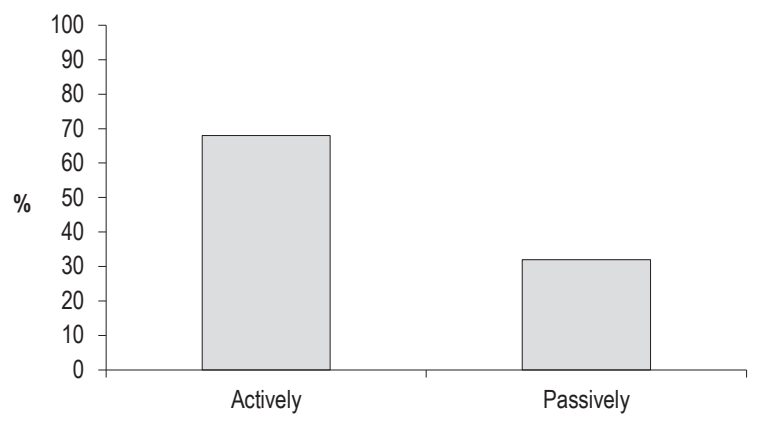

Figure 5. Respondents' leisure time 


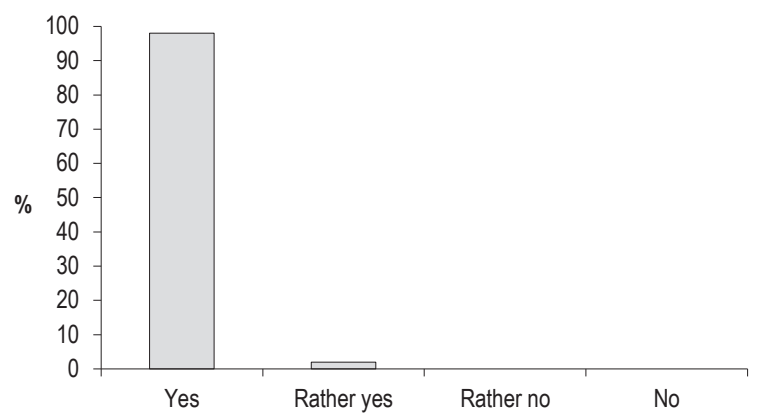

Figure $\mathfrak{G}$. Deriving pleasure from aqua aerobic classes

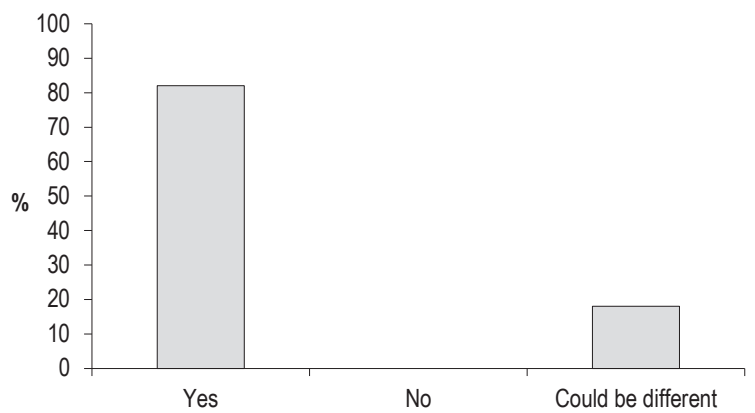

Figure 7. Do respondents like music, which is played during aqua aerobic

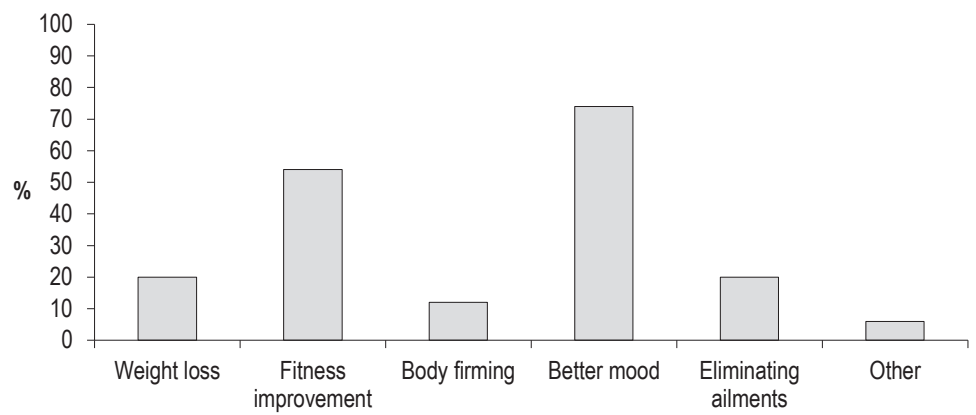

Figure 8. Benefits noticed through participation in aqua aerobic classes 


\section{Discussion}

As expected, the study showed that participants of aqua aerobics classes were women. A similar statement was present in the work of J. Eider (1999), describing a similar form of physical activity that is aerobics. Also Wiażewicz $(2014,2014 b)$ emphasizes the advantage of women in aqua aerobics. Almost $40 \%$ of participants had jobs of an intellectual nature. A little less, 30\% were engaged in physical and intellectual work. Wiażewicz (2014, 2014b) also highlights the advantage of the participation of subjects working intellectually. Eider (2004, 2004b, 2004c) examining the aerobics class participants obtained similar data.

Over $50 \%$ of respondents stated that they lead a healthy lifestyle. In contrast, $30 \%$ of people marked the answer "don't know". Perhaps the public is not aware of the exact definition of a healthy lifestyle. Only $10 \%$ of participants rated their health as very good, $30 \%$ as moderate, and only $12 \%$ answered that they do not have any complaints. Moreover, following healthy diet was declared by more than $70 \%$ of respondents. Olech-Himkowska (2012) obtained similar results for the people "reporting" healthy eating.

The majority of subjects - $82 \%$ - did not smoke cigarettes. Drinking alcohol was admitted by $18 \%$ of respondents. Most of the women taking part in aqua aerobics classes declared active leisure time activities. A similar result was obtained by Olech-Himkowska (2012) which showed that almost $80 \%$ of people engaged in recreational dance prefer active rest.

All participants declared that aqua aerobics classes gives them pleasure. Most women preferred classes, where the "pool noodles" or "mixed" exercises were used, performed using a number of different gears.

Among the notable changes, the largest number of women indicate a better mood after classes. This is consistent with the Pietrusik's (2005) conclusions, who says that aqua fitness is a form of physical activity in the water, with the aim to find the well-being. A similar assumption was placed in Ahn's (2003) work, noting that aqua aerobics gives a significant positive psychological effect. More than half of participants reported improved condition, and $20 \%$ - weight loss. Other results were obtained by Kim and O'sullivan (2013) who noted a significant reduction in body weight in the elderly. Olech-Himkowska (2012) adds that $58 \%$ of respondents noticed changes in the body proportions thanks to dance classes.

Baena-Beato, Arroyo-Morales, Delgado-Fernández, Gatto-Cardia, Artero (2013) reported that exercises in water therapy reduce back pain and also help to improve the quality of life and health in adults with chronic low back pain. A similar conclusion was reached by Svedenhag (1992), who determined aqua aerobics as very effective in reducing pain in patients with arthritis. Wiażewicz $(2014,2014 \mathrm{~b})$ reports that about $96 \%$ of aqua aerobics participants noticed health improvement. Jung, Chung, Kim, Lee, Lee (2014) reported that exercise in an aquatic environment is more effective than training applied on the ground. Kim and O'sullivan (2013) found that aquatic exercises are an effective method to reduce the risk of falling in the elderly.

Knowing the participants' preferences can help to recognize their expectations and increase the attractiveness of classes. Knowledge about the lifestyle of respondents allowed to hold talks with them in the field of proper nutrition and active leisure. Thanks to this, part of the ladies attending aqua aerobics expressed a desire to change their lifestyles and improve diet habits. 


\section{Conclusions}

Based on the results, authors obtained the following conclusions:

1. Although the majority of people declare a healthy lifestyle, it is advisable to continuously spread-information about the need for lifelong physical activity.

2. As many as $30 \%$ of respondents did not know if they lead a healthy lifestyle. Therefore, a greater promotion of healthy behaviors should take place.

3. Aqua aerobics gave pleasure to all participants. Instructors should continue the way of training, taking into consideration some suggestions of the respondents.

4. Aqua aerobics instructors should know more about the group attending classes in order to make the exercises more attractive and effective.

\section{References}

Ahn, Y.D. (2003). Effects of the aquatic exercise and weight training for physical fitness of patients with middle aged man lumbago. The Korean Society of Sports and Leisure Studies, 19, 1301-1316.

Baena-Beato, P.A., Arroyo-Morales, M., Delgado-Fernández, M., Gatto-Cardia, M.C., Artero, E.G. (2013). Effects of different frequencies (2-3 days/week) of aquatic therapy program in adults with chronic low back pain. A non-randomized comparison trial. Pain Medicine, 14 (1), 145-158.

Drabik, J., Resiak, M. (2010). Styl życia w promocji zdrowia. Gdańsk: Wydawnictwo AWF i Sportu im. Andrzeja Śniadeckiego.

Eider, J. (1999). Uczestniczki zajęć z aerobiku. Zeszyty Naukowe Uniwersytetu Szczecińskiego, 16, 39-48.

Eider, J. (2004). Aerobik wodny. Zeszyty Naukowe Uniwersytetu Szczecińskiego, 19, 5-15.

Eider, J. (2004b). Female participants of recreationnal sessions of aquarobics. Annales Universitatis Mariae Curie-Skłodowska Sectio D Medicina, 2 (102), 40-44.

Eider, J. (2004c). Motor Fitness of Women Participating in Aquaaerobic. Journal of Human Kinetics, 11, 47-52.

Eider, J., Eider, P. (2006). Rekreacyjne zajęcia z aerobiku wodnego w naturalnym środowisku. In: J. Eider (ed.), Człowiek i środowisko przyrodnicze Pomorza Zachodniego. Aktywność fizyczna osób w różnym wieku - teoria i praktyka (pp. 120-125). Szczecin: Wydawnictwo Naukowe Uniwersytetu Szczecińskiego.

Jung, J.H., Chung, E.J., Kim, K., Lee, B.H., Lee, J.Y. (2014). The Effects of Aquatic Exercise on Pulmonary Function in Patients with Spinal Cord Injury. Journal of Physical Therapy Science, 26 (5), 707-709.

Katz, V.L. (2003). Exercise in water during pregnancy. Clinical Obstetrics and Gynecology, 46 (2), 432-441.

Kim, S.B., O'sullivan, D M. (2013). Effects of Aqua Aerobic Therapy Exercise for Older Adults on Muscular Strength, Agility and Balance to Prevent Falling during Gait. Journal of Physical Therapy Science, 25 (8), 923-927.

Menotti, A., Puddu, P.E., Maiani, G., Catasta, G. (2014). Lifestyle habits and mortality from all and specific causes of death: 40-year follow-up in the Italian Rural Areas of the Seven Countries Study. The Journal of Nutrition Health and Aging, 18 (3), 314-321.

Menotti, A., Puddu, P.E., Maiani, G. ,Catasta, G. (2015). Lifestyle behaviour and lifetime incidence of heart diseases. International Journal of Cardiology, 201, 293-299.

Mędrela-Kuder, E. (2004). Niektóre elementy stylu życia młodzieży aktywnie uprawiającej sport. Kultura Fizyczna, 1-2, 23-26.

Mosakowska, M. (2007). Aquafitness - sport całego życia. Kultura Fizyczna,1-2, 21-26.

Nowak, M. (2008). Aktywność fizyczna w prozdrowotnym stylu życia kobiet. Poznań: Wydawnictwo Akademia Wychowania Fizycznego im. E. Piaseckiego w Poznaniu.

Olech-Himkowska, O. (2012). Styl życia uczestników koszalińskich szkół tańca. Zeszyt Naukowy Uniwersytetu Szczecińskiego, 28, 237-249.

Pietrusik, K., Mroczek, B. (2003). Aqua Aerobik. Body Life, 3, 24-27. 
Pietrusik, K. (2005). Pływanie - nauczanie i doskonalenie oraz wybrane elementy aqua fitness. Podręcznik dla instruktorów rekreacji ruchowej - pływanie. Warszawa: Wydawnictwo TKKF.

Prinelli, F., Yannakoulia, M., Anastasiou, C.A., Adorni, F., Di Santo, S.G., Musicco, M., Scarmeas, N., Correa Leite, M.L. (2015). Mediterranean Diet and other lifestyle factors in relation to 20-year all-cause mortality: a cohort study in an Italian population. British Journal of Nutrition, 113 (6), 1003-1011.

Sęk, H. (2000). Zdrowie behawioralne. In: J. Strelau, D. Doliński (eds.), Psychologia. Podręcznik akademicki (pp. 542-543). Gdańsk: Wydawnictwo GWP.

Svedenhag, J. (1992). Running on land and in water: comparative exercise physiology. Medicine and Science in Sports and Exercises, 24, 1155-1160.

Sygit, M., Sygit, K. (2008). Wychowanie zdrowotne. Szczecin: Wydawnictwo Naukowe Uniwersytetu Szczecińskiego.

Wiażewicz, A. (2014). Rekreacyjne zajęcia aqua aerobiku w opinii szczecińskich uczestników. In: J. Eider (ed.), Turystyka i rekreacja w teorii i praktyce (pp. 87-96). Szczecin: Wydawnictwo Naukowe Uniwersytetu Szczecińskiego.

Wiażewicz, A. (2014b). Uczestnicy zajęć aqua aerobiku na wybranych szczecińskich pływalniach. In: J. Eider (ed.), Turystyka i rekreacja w teorii i praktyce (pp. 97-106). Szczecin: Wydawnictwo Naukowe Uniwersytetu Szczecińskiego.

Zysiak-Christ, B., Figurska, A., Stasikowska, I. (2010). Metodyczne podstawy aqua fitness. Wrocław: Wydawnictwo Aqua Fit.

Cite this anticle aS: Drohomirecka, A., Wojciuszkiewicz, J. (2016). Opinion about Exercises in Water and Lifestyle of Women Attending Aqua Aerobics Classes. Central European Journal of Sport Sciences and Medicine, 13 (1), 101-108. DOI: 10.18276/cej.2016.1-10. 